\title{
MIR376C wt Allele
}

National Cancer Institute

\section{Source}

National Cancer Institute. MIR376C wt Allele. NCI Thesaurus. Code C96011.

Human MIR376C wild-type allele is located in the vicinity of $14 q 32.31$ and is approximately 86 bases in length. This allele, which encodes MIR376C pre-miRNA, plays a role in either transcriptional or translational regulation of target sequences. 